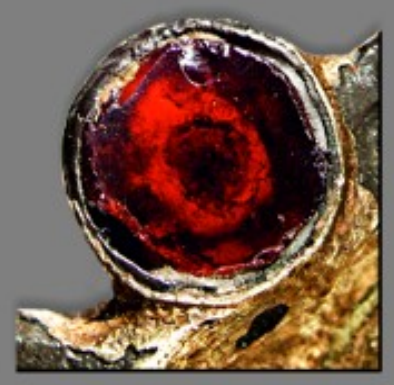

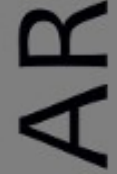

$\sim$

ш
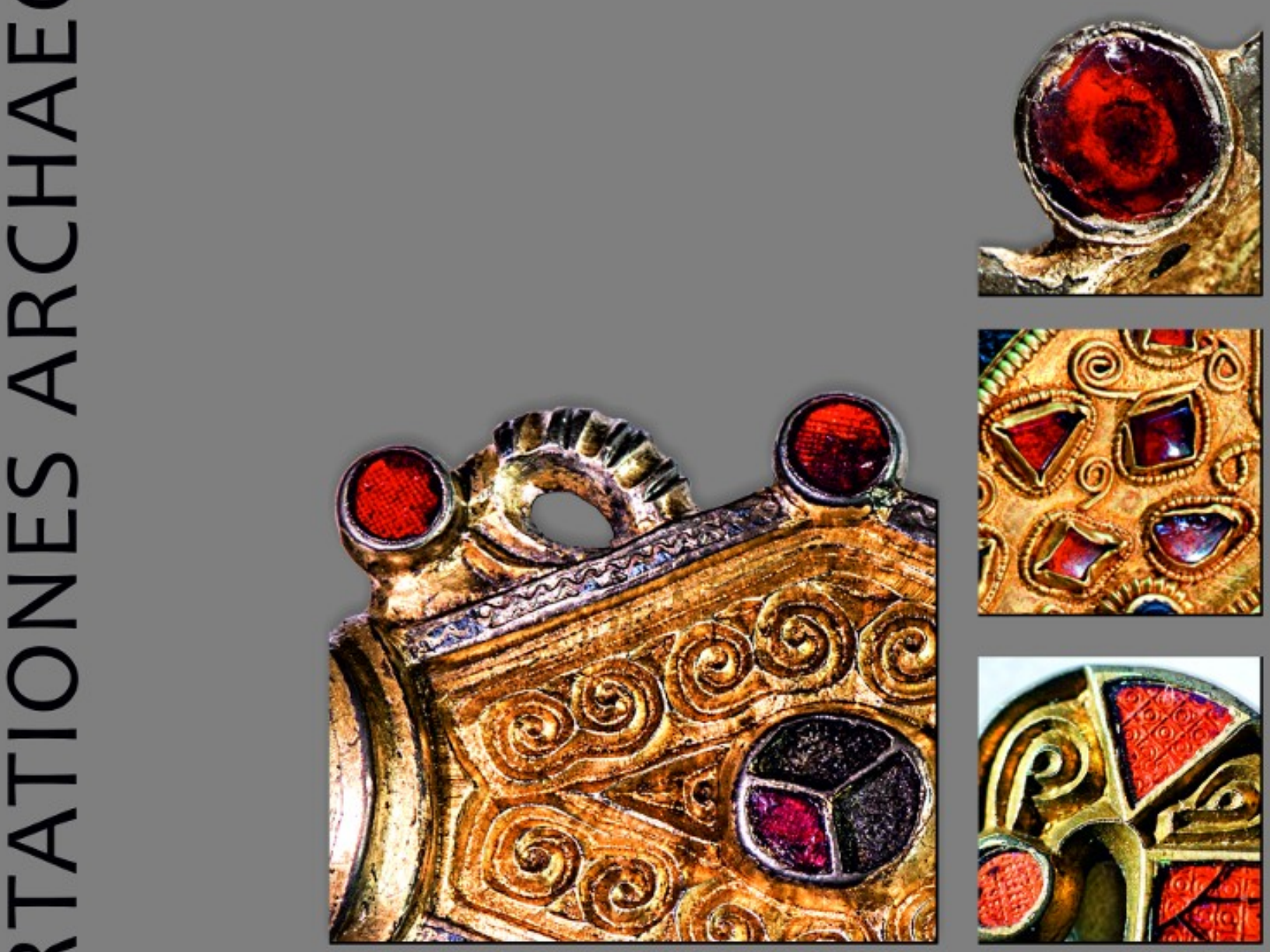

E

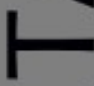

œ

山

n

ก

$\overline{0}$
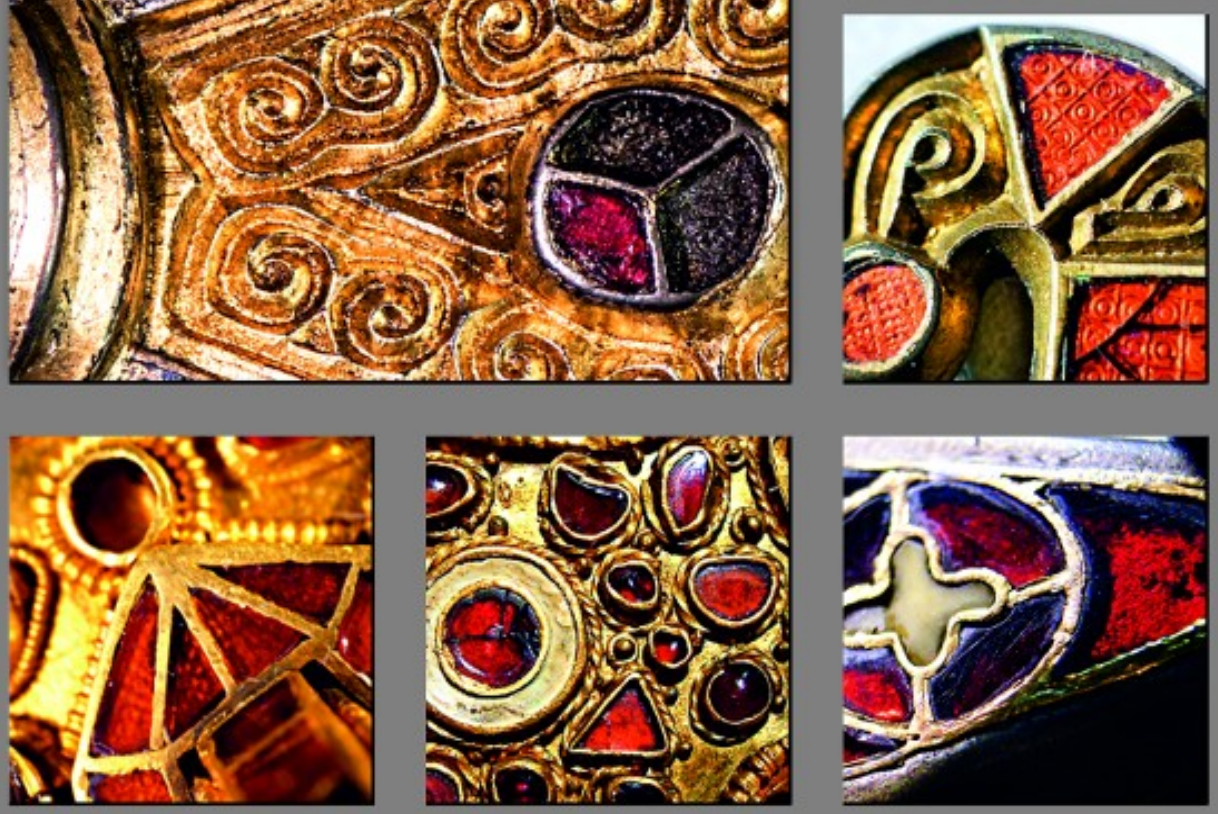

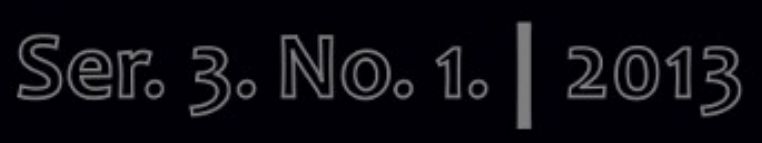




\section{Dissertationes Archaeologicae ex Instituto Archaeologico}

Universitatis de Rolando Eötvös nominatae Ser. 3. No. 1.

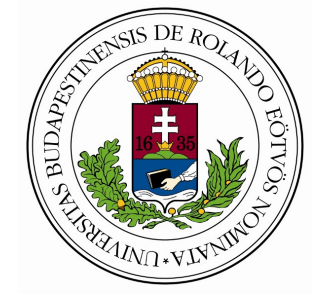

Budapest 2013 
Dissertationes Archaeologicae ex Instituto Archaeologico

Universitatis de Rolando Eötvös nominatae

Ser. 3. No. 1.

Editor-in-chief:

DÁvid BARTUS

Editorial board:

LÁSZLÓ BARTOSIEWICZ

LÁSZLÓ BORHY

ISTVÁN FELD

GÁBOR KALLA

PÁL RACZKY

Miklós SzABÓ

TIVADAR VIDA

Technical editors:

DÁvid BARTuS

GÁBOR VÁCZI

ANDRÁs BöDŐcs

Proofreading:

Zsófia KondÉ

SzILvia SzÖLlősI

Available online at http://dissarch.elte.hu

Contact: dissarch@btk.elte.hu

\section{$\underline{\text { PKP }}$ \\ PUBLIC \\ KNOWLEDGE \\ PROJECT}

(C) Eötvös Loránd University, Institute of Archaeological Sciences

Budapest 2013 


\section{Contents}

\section{Articles}

Melinda TORBÁGYI - István VIDA

The coin hoard of Abasár

Anikó BózsA

21

Roman mirrors from a private collection in the Hungarian National Museum

Lajos JuHÁsz

45

The Biesheim cameo - a reinterpretation

\section{Methods}

Péter CsIPpÁN

$A z$ állatcsont, mint információhordozó leletanyag

Kata DÉvAI

Terminológiai alapfogalmak régészeti korú üvegtárgyak elemzéséhez

Lőrinc TimáR - Zoltán Czajlik - Sándor Puszta - Balázs Holl

$3 D$ reconstructions using GPR data at the Mont Beuvray

\section{FIELD REPORTS}

Zsolt MESTER

Excavation at a new Upper Palaeolithic site of the Eger region (Northern Hungary)

László BORHY - Dávid BARTus - Emese SzÁmadó

Short report on the excavations at Brigetio (Szőny-Vásártér) in 2013

Dénes HulLÁm - Zsófia RÁcz

Report on the participation of the Eötvös Loránd University at the Wielbark Archaeological Field School in Malbork-Wielbark, Poland

Gábor VÁczi - Dávid BARTus

Short report on the excavations at the site Makó - Igási Ugar

Maxim MoRdovin

Short report on the excavations in 2013 of the Department of Hungarian Medieval and Early Modern Archaeology (Eötvös Loránd University, Budapest)

\section{THESIS ABSTRACTS}

Kitti KÖHLER

Biological reconstruction of the Late Neolithic Lengyel Culture 
Cultural connections and interactions of Eastern Transdanubia during the Urnfield period

Orsolya LÁNG

Urban problems in the civil town of Aquincum: the so-called „northern band”

Nikoletta SEY

Questions of bronze workshops in Roman Pannonia

Kata DÉvaI

Glass vessels from Late Roman times found in graves in the Hungarian part of Pannonia

Eszter HORvÁTH

Gemstone and glass inlaid fine metalwork from the Carpathian Basin:

the Hunnic and Early Merovingian Periods

Gergely SzEnTHE

Vegetal ornaments in the Late Avar decorative art

Péter LANGó

Relations between the Carpathian Basin and South East Europe during the 10th century.

The evidence of the minor objects

Ciprián HoRvÁTH

The Cemeteries and Grave Finds of Györ and Moson Counties from the Time

of the Hungarian Conquest and the Early Árpádian Age

András Sófalvi

The border- and self-defence of Szeklers from the Medieval Age till the Age of Principality.

Castles and other defence objects in the settlement history of Udvarhelyszék 


\title{
Urban problems in the Civil Town of Aquincum: the so-called „northern band”
}

ORSOLYA LÁNG

Aquincum Museum

lang.orsolya@mail.iif.hu

\begin{abstract}
PhD thesis submitted in 2013 to the Archaeology Doctoral Programme, Doctoral School of History, Eötvös Loránd University, Budapest under the supervision of Dénes Gabler.
\end{abstract}

\section{Topic and aims of the dissertation}

The more than 120 years of archaeological excavations at the Aquincum Civil Town have brought to light less than half of the ancient town. Thorough publishing of the excavated remains and finds was only possible before World War II. Because of the growing number of investment-led excavations, in the last decades, archaeologists have only been able to publish the preliminary results of their work. Separation of the building periods or evaluation of the finds are rarely carried out these days. The first attempt to re-evaluate old excavation documentation was the MA thesis of the author: find material of the excavation in 1965 of the Aquincum macellum was connected to field observations. Due to this work, a more precise picture of the building periods and functions of the complex could be established. Thus, it now seems useful to evaluate more unpublished or only partially (from preliminary reports) known excavations. The area of the North-East zone of the Aquincum Civil Town was chosen, partially, because there were still many excavation materials to be evaluated here and in part because these excavations were carried out in a relatively small, but contiguous area where, hopefully, the different building periods could be reconstructed in an area where control-excavations can still be carried out.

The area is bordered by Road "A" (continuation of the cardo, Road "C") on the west and the $d e$ cumanus running down to the river (Road " $\mathrm{D}$ ") on the south. Its northern border may have been the east-west Roman road running below modern Keled Street, or it may also have stretched to the northern town wall. Its eastern border is hard to determine because the modern north-south street runs here (Sujtás Street) and the housing estate below which only small-scale excavations were carried out at the beginning of the twentieth century. The area falling beyond the archaeological park was not considered in this dissertation due to the lack of archaeological research and data (Fig. 1).

This region of the town has been given several names during the research: the name "Central mass" referred to its modern form, created from the spoil heaps of nearby excavations. More recently its name has been based on its orientation: "the northern part of Road "D", "northern band" or "North-East zone". Even though, presently the name "northern band" is more commonly used, this area will be called the "North-East quarter or part" in this dissertation. This area has always been associated with industrial and commercial activities related to the busy road that ran through here and the remains of the strip buildings visible on the surface. 


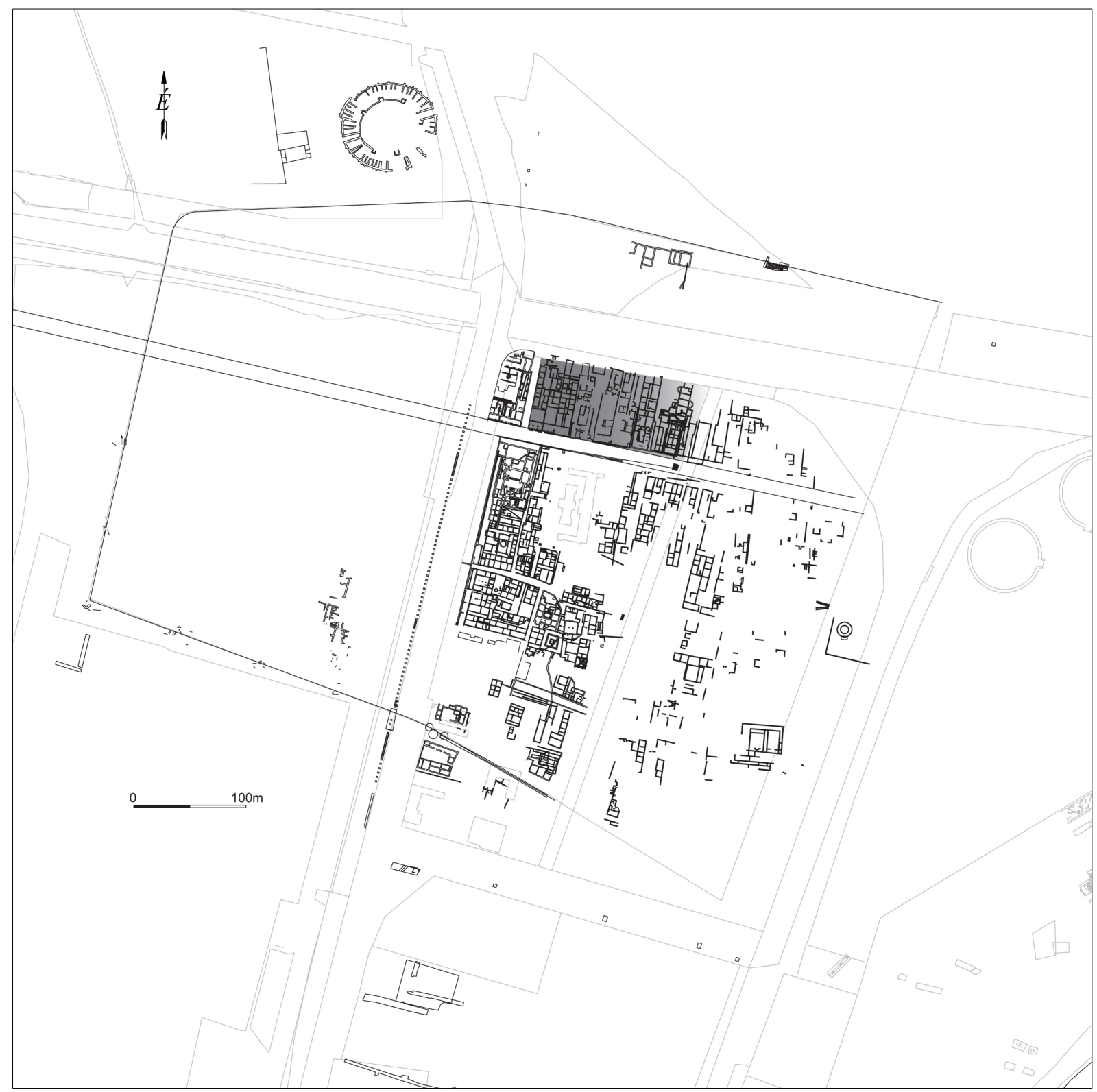

Fig. 1 .

The dissertation concerns excavation materials from the following buildings within the archaeological park:

- West and central wing of Building nr. I - the so-called Basilica: T. Nagy 1961-1962 (results of the material evaluated by the excavator is used here with a partial reevaluation of the finds).

- East wing of Building nr. I - the so-called Basilica: J. Szilágyi 1966-67; K. Póczy 1972; P. Zsidi 1990; E. Márity 1991-92.

- Building nr. XXVI - the so-called sanctuary of Diana: J. Szilágyi 1966-67; E. Márity 1993.

- Building nr. XXVI: J. Szilágyi 1966-67. 
- Building nr. XXIX - the so-called glue-manufacturing workshop: J. Szilágyi 1944-47; O. Láng 2004-2007.

With the evaluation of the excavation documentations and find materials from the NorthEast quarter of the Aquincum Civil Town, the main purpose of the dissertation is the periodization of the buildings, their relative and absolute chronology and decide about what went on in this town quarter, the buildings and the rooms (industrial or commercial nature?) and ultimately, the reconstruction of the building history in this zone of the town. Hopefully, a more precise picture of the history of this part of the town and the function of its buildings can be drawn and new data added to the history of the Civil Town as a whole.

Answers were sought to the following questions:

- Is it possible to reconstruct a contiguous settlement structure in different periods in the North-East zone of the town?

- Is the "internal" periodization identified in the North-East zone consistent with the chronological sequence in the other parts of the town described earlier?

- When was the area first used by the Romans and how was it used (civilian or military)?

- When and how did the history of this quarter come to an end?

- Is it possible to determine the function of the stone buildings, or confirm the functions identified by earlier researchers in light of the new evaluations?

- Is it really an industrial-commercial quarter and if it is, then how does it fit into the topographical framework of the Civil Town?

\section{Dissertation Structure}

The results of the excavations carried out in the North-East quarter of the Civil Town are considered in several chapters within this dissertation. Following the introduction (1) the North-East quarter is defined and its various names described (2.1). The detailed and diverse research history (2.2) is followed by a chapter introducing the evaluation methodology (2.3).

The evaluation of the excavation documentation of the North-East zone is topographically based and runs from east to west according to the visible building remains numbered with Roman numerals. Parallel with the building numbers there are four big sub-chapters: the first concerns different parts of the westernmost structure, Building nr. I (Basilica), re-excavated several times and called a variety of names (western and central wing, eastern wing and Peacock-house). These are described separately (2.4.1-4). The second sub-chapter deals with the excavations at the neighbouring Buildings nrs. XXVI and XXVII, called the "Central mass" or/and the "Diana sanctuary" (2.5.1-2). The third part is about the evaluation of the material of the several times re-excavated Building nr. XXIX (2.6). The last sub-chapter (2.7) concerns with buildings that lack any excavation documentation that were excavated in the 19th century, so only extant publications can be relied on (Buildings nr. XXVII, XXVIII, XXX, XXXI). All chapters of the evaluated excavation documentations are followed by a summary of its "internal" building chronology (2.4.2.3, 2.4.3.3, 2.4.4.3, 2.5.1.3, 2.5.2.3 and 2.6.3). 
The summary of the building history of the quarter follows the evaluation of the excavation documentation and "internal" chronologies. The "internal" chronologies are compared to each other, in order to set up the relative chronology for the whole of the North-East zone. (2.8 and Fig. 2). At the end of this part of the dissertation there is a separate chapter dedicated to the building materials used in the North-East zone (2.9).

The following chapter deals with datable finds or those that are important from the functional point of view and stratigraphically valuable. These objects were assigned to the building phases and helped in dating different periods (2.10). Thus, separate chapters are dedicated to the Samian ware material (2.10.1.1), the amphorae (2.10.1.2), coins (2.10.1.3) and Pannonian stamped pottery (2.10.1.4). Oil-lamps, mortaria and turibula were evaluated mainly by counting but they also provide important information on how archaeological features were used as well as the period of early settlement (the degree of Romanization) (2.10.1.5). Individual finds and special contexts were described in a separate chapter containing data on the function of certain features and ultimately, on the dating and function of the town quarter as a whole as well (2.10.1.6). Evaluating the finds enabled us to set time limits for most of the building periods, so that the absolute chronology of the North-East quarter could be delineated (2.10.2 and Fig. 3).

The historical framework of the quarter could also be established following the evaluation of the documentation and finds as well as reconstruction of the settlement structure and the description of the role of the North-East quarter within the Aquincum Civil Town. It was even possible to interpret this data (2.11). Several ideas and suggestions have been published about the function of certain buildings and the quarter itself over the last 120 years of research. By re-evaluating the documentation and finds it has become possible to update, refute or confirm these ideas. For this reason, a separate sub-chapter was dedicated to the problem of the so-called Basilica (2.12.1); the "Diana sanctuary" (2.12.2); the workshop of Building nr. XXIX (2.12.3); the quarter's public utility network (2.12.4) and the so-called strip-building (2.12.5), the characteristic 2nd-3rd century AD house type found in this zone. The dissertation ends with a list of abbreviations (3) and the bibliography (4). The list of the US numbers used for evaluation of the documentation (5) and the figures (6) are placed in a separate volume.

\section{Evaluation methods}

Different standards of evaluation were used to document the excavations carried out in the last 120 years in the North-East zone of the town and evaluated in this dissertation. As no documentation is available and no control excavations were ever carried out in the three buildings located here (Buildings nrs. XXVII, XXX, XXXI), first excavated in the 19th and around the middle of the 20th century, only a summary could be made of them in a separate chapter. The "wings" of Building nr. I (the so-called Basilica) were also excavated several times in the 19th-20th centuries They were documented by a traditional layer-description method. Only in the case of T. Nagy 's excavation documentation of the western and central wing of the same building do we find objectively numbered archaeological features and proper stratigraphy. More recent research carried out in Building nr. XXIX were documented using the Harris matrix system (US numbers, matrix). 
It was necessary to deal with all site observation data and finds from the differently documented excavations within a single integrated system. Thus, it seemed most appropriate to use the Harris matrix system. In cases where the excavator was not the author of this dissertation, all archaeological features described in the diaries were numbered, employing all handwritten and typed documentation. These features were placed afterwards into a matrix based on the site drawings and photos. This method was not used when evaluating T. Nagy's excavation results as he had already separated the various building phases. These phases could be used as comparative material.

The method described above permitted the creation of an "internal", relative chronology for each excavation so they could be compared to each other and finally set up in a kind of "concordance table", i.e. the relative chronological sequence of the North-East quarter itself (Fig. 2). The find material could afterwards be connected to the identified building phases to help create absolute dates for the phases.

However, two major problems had to be faced during this work. One was the fact that certain buildings were not excavated in a regular manner (from north to south or west to east) so that a single area could be re-dug several times by generations of archaeologists. This is the reason that, while the central part of the eastern wing of Building $\mathrm{nr}$. I is relatively well known, almost nothing is known about its southern part. The diaries of the different excavators sometimes contained conflicting data about the same feature causing problems with the interpretations. The other major problem was the usability of the find material, since if an archaeological feature was described inaccurately, the finds coming from it became suspect from the point of view of dating and could only be used for artefact counts or providing information on the function of the features. Due to the above-mentioned problem, only a part of the total find material could be used for dating building phases.

Despite these problems, converting the various excavation-documentation into an integrated system proved successful in the case of the North-East zone in the Civil Town as well: based on the identified building phases and the finds connected to them the building history of this quarter could hopefully be reconstructed and provide new data on the activities that took place in this zone in the settlement.

\section{Building history of the North-East quarter}

The evaluation of the documentation of the North-East zone of the town permitted the periodization of this part of the settlement and the reconstruction of the building history of the quarter to be set up. The "internal" relative chronology created for each excavated section was complemented by an as yet unpublished chronological framework for the eastern wing of Building nr. I. established by K. Póczy and that created by T. Nagy for the western and central wings of the same building (the so-called Basilica). Thus, eight main building phases could be distinguished in the North-East quarter of the Aquincum Civil Town.

\section{Phase 1}

The earliest building phase in this part of the settlement is represented by a few semi-subterranean pit houses, pile-structures, a horseshoe-shaped ditch-and-posthole construction, 
pits and an east-west oriented ditch running along Road " $\mathrm{D}$ " in the western part of the area. The archaeological features were concentrated on the north and despite the lack of systematic excavation the ditch already reflected the presence of Road "D". The dwelling features (pit houses) appear in a band indicating the presence of some kind of systematic settlement structure. Excavation data also revealed that the area sloped heavily from west to east in the direction of the Danube, rising slightly from north to south. The eastern part of the studied area (the zone of Building nr. XXIX) turned out to be a marshy, meadow-like place, not yet occupied in this period. Only T. Nagy has so far suggested an absolute date for this phase (the so-called "Prebasilical I" phase between the reign of Vespasian and Domitian).

\section{Phase 2}

This building phase was characterized by a denser system of features again placed in a bandlike system and with different functions: pavements, the imprint of a wooden beam, circular pits (waste pits?), a well, a detail of a room with two segments of clay-brick walls and pavement (a building?) and postholes. To the east of these features were two rectangular, semisubterranean pit houses with plastered and painted adobe walls and an inside oven. The buildings were reinforced by posts in this period. The two north-south oriented buildings were located close and parallel to each other. A small, north-south oriented street already existed between later Building nrs. XXVII and XXVIII to the east of the above-mentioned buildings. The settlement structure of this period is slightly better known: while there were large open spaces to the south, towards the east-west road, a denser system of pit houses and other features occupied the northern part of the North-East quarter. This horizon was still attributed to the "Prebasilical I" phase by T. Nagy.

\section{Phase 3}

Buildings, partly with stone foundations but mainly from purely adobe walls, rammed clay and gravelled floors, wells and an oven, characterize the North-East zone in this period. Although no coherent settlement structure can be reconstructed yet, certain tendencies can already be delineated. The western part of this zone (the central and eastern wings of Building nr. I) was occupied by a building with a large room and a well in it. The building had rammed clay floors and an open space to the south (with a gravelled floor). Some smaller rooms were discovered that also had rammed clay floors and a large pit below the eastern wing of Building nr. I. Despite its quite fragmentary ground-plan it appears to have been a building with a large central room (atrium?) and its western perimeter wall suggests that a regular system already existed in this period. Large-scale landscaping activities can be presupposed on the eastern edge of the area (below Building nr. XXIX) to level the steep slope. Even though no coherent plan can yet be put together from the fragmentary walls decorated with frescos, the function of the different sections are clear: traces of industrial activities can be observed along Road "D" (metal working - slag in the layers and vessels), a stone paved area (courtyard?) and channel indicate the place of the dwelling in the north. Functions can already be distinguished and regular plot division can be detected based on the above-mentioned features. This is the time when the insula-system was marked out. This phase, characterized by stone foundations and adobe walls was dated to the first decades of the 2nd century $\mathrm{AD}$ (the "Prebasilical II" period) based on the Samian ware found in Building nr. I by T. Nagy. 


\section{Phase 4}

The first stone construction appeared in this period in the North-East zone (and possibly also other parts of the town), the period has been called the "limestone-period" by K. Póczy. Most of the buildings had stone foundations with upper adobe walls by this time. This era is characterized by the consolidation of the borders of the plots, the appearance of strip buildings and the "filling-in" of the insulae. The plot divisions were only slightly modified in the later periods. Building nr. I. was already divided into two wings (west and central): two corridor-like rooms with rammed clay floor opened onto Road " $\mathrm{D}$ " in the western wing while there are two other smaller rooms with the same type of pavement opened to Road " $A$ ". Larger rooms with rammed clay floor were identified in the central wing of the building, with a melting oven in one of them. A large, stone paved courtyard followed both of the wings to the north. A building divided by a narrow alley was discovered below the eastern wing of Building nr. I. It had gravelled and rammed clay floors. Fragments of walls discovered to the north, on one hand, indicate that the stone paved courtyard did not continue to the east, and on the other hand, an impluvium-like construction and rammed clay floor suggest this may have been a dwelling, possibly with an atrium. The eastern perimeter wall of Building nr. XXVI and the western perimeter wall of Building nr. XXVII as well as a layer in the street separating the buildings can also be connected to this phase. A narrower and possibly shorter version of Building nr. XXIX was also constructed at this time. The southern part of this latter building was divided into large rooms where metal-working was still practiced (3 smaller melting ovens and slag) while the northern, dwelling area also incorporated a well and an open courtyard with a baking oven. The building was bordered by a stone paved street on the east. Analogies from other parts of the settlement as well as historical data help in dating this building phase. Thus, the changes in topography can be explained by the fact that Aquincum became the capital of the province in $106 \mathrm{AD}$. T. Nagy dated the beginning of this phase of Building nr. I (with its two wings) to the beginning of the reign of Hadrian and ended it by the time of the Marcomannic wars (the "Basilica" I phase). A coin of Trajan, found in the foundation of a rammed clay floor in one of the rooms of the western wing of Building nr. I, also confirms this date (i.e. the end of phase 3).

\section{Phase 5}

Walls belonging to this period in the North-East zone already display coherent ground plans. According to T. Nagy, the western and central wing of Building nr. I. became the basilica of the town (for the function, see below). This complex had large covered room opening to Road "D" with a portico and large open spaces completed with a stone paved courtyard in its northern end. A base was discovered in this courtyard together with the head of an imperial statue. A central corridor, with small rooms opening from both sides, was formed in the northern part of the eastern wing of Building nr. I. A courtyard opening with a portico on Road "D" lies in the southern part of the building alone. An apse and a ditch were also added to this building on the north together with a well. Only sporadic data is available from the area of Building nr. XXVI including an oven (?) and the eastern perimeter wall of the building. The complex of the so-called "Diana sanctuary" was also added to the latter building at this time. However, neither the finds nor the ground plan of the complex demonstrate that it actually had a sacred function, especially as it is organically connected to Building nr. XXVI. Building nr. XXIX took on its final form in terms of both length 
and width and filled the entire plot: a long central room or corridor occupied the southern part of the building, while there are larger rooms with rammed clay floors and an open courtyard in the northern section of the structure. This latter area had wooden columns (a canopy, an atrium-antecedent?). A new oven was also constructed here. The workshop and the dwelling part are clearly distinguishable in this period too. Metal-working was replaced by glue-making and possibly tanning and horn working in the southern section of the structure, which perhaps as the result of the economic changes following the Marcomannic wars. "Wall-pushing" or street-narrowing is a typical feature of the period: this phenomenon can also be observed in Road "C" and in nearly every building (the eastern wing of Building nr. I, Building nr. XXVI and Building nr. XXIX) in the North-East zone of the town. Perimeter walls were moved slightly to the east, which may be partially connected with the re-marking of the insula-system in the Severan era and partially with the fact that by that time the flourishing settlement tried to find more space for the burgeoning population. By this time, the ground plans of Buildings nr. I, XXVI, XXVII and XXIX are all of the strip building type. This type was exemplified by a large (partly open?) room opening onto the main road while dwelling rooms (possibly also with a more workshop character) opened from the corridor, constructed along the long axis of the building. Functions of certain buildings or rooms can only be identified for the western and central wings of Building nr. I ( a mansio or collegiabuilding?) and Building nr. XXIX (the glue-manufacturing/tanning workshop). The phase was attributed to the "Basilica II" era by T. Nagy and associated with the re-building work that took place at the end of the 2nd century AD. Nagy suggested that this building phase ended around the middle of the 3rd century AD.

\section{Phase 6}

Most of the building remains still visible in the North-East zone today can be attributed to this phase. All of the structures are strip buildings with some also belonging to the central corridor-type. Unfortunately, no archaeological features could be connected to the western and central wing of Building nr. I so it is not clear if anything actually changed. The eastern wing of the same building had a central corridor and some kind of functional division is also observable: large rooms (shops, workshops?) were formed in the southern part of the building while three rooms were placed symmetrically on each side. These were partially heated rooms with wall paintings that opened from both sides of the central corridor to the north. A back courtyard, possibly used for workshop purposes, continued in the northern end of the building, with a terrazzo lined pipe, channel and well. Even though there are no data from the major part of Building nr. XXVI, the very questionable complex of the so-called "Diana sanctuary" - to which more walls belong to the south - was still organically part of the building. This complex only underwent minor alterations in this period similarly to the so-called " $\beta$ hall" to its east. The stratigraphic layers from the latter structure could not be examined due to modern disturbances. The final room division of Building nr. XXIX also dates to this period. A central room with symmetrically placed smaller rooms on both sides was constructed in the southern part. Glue-manufacturing/tanning activities still went on in the southern workshop rooms paved with rammed clay floors with other features including soaking pits, platforms, an oven and a press slab that all attest to such activities. Rooms, also with rammed clay floors, were constructed in the northern, dwelling area of the building. Its northern courtyard was divided by pillars and walls. A new oven and a channel were also 
located here. The functions of the rooms can be best reconstructed in this phase, dated by K. Póczy to the first half - middle of the 3rd century AD, even though E. Márity dated walls belonging to this phase to the 4th century $\mathrm{AD}$.

\section{Phase 7}

It is not yet clear which parts of certain buildings in the zone North-East of the town were reused in this period, as late layers and features fell victim to the continuous quarrying activity in the centuries that followed as well as the first excavations and wall-conservation work of the 19th century. The room division of the previous period possibly survived in the eastern wing of Building nr. I, where there was only a narrowing of an entrance, renovation of a wall and a pavement that divided a room in two and the construction of a podium-like structure. Tools and finds related to metal-working were discovered in the building and can be related to this phase. The most interesting construction of the time was a large room built above the walls of the northern part of the eastern wing of Building nr. I (the "trapezoidal room"). It had a terrazzo pavement on which a bronze oil-lamp in form of a peacock with enamel inlay was found. The excavator dated the room to the 4th century AD based on this oil-lamp and interpreted it as a sanctuary in her manuscript. None of these ideas (dating and/or function) can be demonstrated either through the documentation or the find material. In the eastern part of this quarter, the southern part of Building nr. XXIX can still be associated with glue-manufacturing/tanning in this period. The rooms in its northern, dwelling area had terrazzo pavements and most had wall paintings. Its central, open courtyard became the atrium. The phase can be dated to the first half of the 3rd century AD based on the find material (coins, Samian Ware) and the walling technique used for the "trapezoidal room" (opus spicatum).

\section{Phase 8}

Only fragmentary features can be connected with the latest phase observable in this zone. Part of a paved road (or floor?) was discovered at the northern end of the eastern wing of Building nr. I, possibly a shifted part of the Roman east-west road ("D1") that runs below modern Keled Street. The earlier rammed clay floor of the praefurnium in the eastern wing of Building nr. I may have been renewed, although it is uncertain whether the room still retained its original function. Industrial activity (glue-manufacturing/tanning) may still have gone on in Building nr. XXIX: small, hastily constructed rooms were inserted into the busy, street-front part of the building facing the neighbouring Third Bath. The absolute dating for the period is unclear.

\section{Dating of the find material and the building periods}

It was necessary to examine the find materials from each excavation in order to date and evaluate the certain building periods. Descriptions connected to the finds were "switched" to US numbers during the evaluation process and classified within the building phases. The absolute chronological framework of a certain phase was set up based on comparison of the date of manufacturing/use of the finds belonging to a particular phase (Fig. 3). However, it was not possible to evaluate all the finds that came to light in the North-East zone of the town (18,492 specimens). Therefore groups of such finds were chosen. These finds already 
had absolute dating value and/or provided data on the function of rooms or buildings. Not even this "restricted" material was entirely useful for dating: finds could only be connected to half of the identified building phases. Only those finds were used for dating that came from well defined layers. In case of Building nr. I (excavation of T. Nagy), the already evaluated and partially published material was re-evaluated in the present dissertation. In certain cases (Building nrs. XXVIII and XXXI), no find material was available, so these could not be examined. The Samian Ware material, amphorae, Pannonian stamped pottery (PGW), coins, individual finds and contexts (decorated mother-of-pearl shell, a rigid heddle, gem, terracotte statuettes, a fragment of a glass cup, finds from the horseshoe-shaped construction, a pot and a bone pin in it from a pit) were used to date the building periods absolutely. Mortaria, oil-lamps and turibula were counted and compared to decide on the degree of romanization at the settlement and also decide about the function of building-segments. Find counts were also carried out on certain groups of finds: diagrams were made up to demonstrate their distribution among the excavations and the buildings, while the location of the finds was also marked on maps. Diagrams were also made of the groups of finds based on the building phases to which they belonged to. Although it was clear, that the results of the analyses should be treated with caution (even the reliably stratified finds were found in levelling layers. The objects could have arrived in their find spot from another part of the settlement) the examinations of different find-groups produced the same results, whether connected to territorial or chronological distribution of the finds supporting site observations on building phases. All in all, it seemed very useful to carry out these analyses, because at least broad tendencies and main characteristics could be demonstrated (for example: separating the dwelling and out-building functions within a house, reflecting the economical crises related to the Marcomannic wars or those from the middle of the 3rd century AD). Parts of the find material evaluated here are also subjects of other projects and $\mathrm{PhD}$ dissertations (Samian ware, amphorae, Pannonische Glanztonware vessels). The results of these works - especially their dating - were also used here indicating their provenance.

\section{The main results of the evaluation of some find-groups}

\section{Samian ware}

More than half of the 2000 specimens of Samian ware could be evaluated stratigraphically and provided good dating evidence from Phase 2 onwards. The relief-decorated pieces were primarily examined because of their dating value. The examination showed that North Italian and South Gaulish (La Graufesenque, Banassac) products were predominant in the early life (Phase 2) of the settlement, which is rather surprising as only a few North Italian pieces had been known previously. From Phase 3 onwards - i.e. the time of real urbanization at the settlement - the number of Central Gaulish Samian ware increased due to the lively economic environment. A large number of earlier Samian ware fragments (North Italian, South Gaulish) were still found in layers connected to Phases 4 and 5, possibly the result of widespread levelling activities connected to the large amount of construction at this time. Products of the Rheinzabern workshops dominate in Phase 6. Unfortunately, the last observable phases in the North-East quarter (Phases 7-8) could not be dated by Samian ware: apart from the many earlier, Central Gaulish fragments only a very few late pieces could be identified (Westerndorf, Pfaffenhofen). 


\section{Amphorae}

Altogether 260 amphorae fragments came to light in the North-East quarter of the town, of which only a part was stratigraphically useful and provided dating evidence for Phases 1-4. Material from Phases 5-8 seemed much more homogeneous, mainly dating to the last decades of the 2 nd and the 3 rd century AD. The examination of the sherds revealed that Dr. 2-4, Rhodian, Schörgendorfer 558 and Dr. 6B were the most frequent types in Phase 1 and 2, which support the idea that the early settlement had a romanized character. During Phase 3 (period of urbanization) the spectrum of amphorae broadened and other types appeared such as the - otherwise very rare - Camulodunum 189 type, or Aquincum 78 and Zeest 90. Dr. 7-11 type amphorae appeared from Phase 4 onwards. Even though amphorae of Bojović 549/554 type dominated in the following phases (5-8) other rare types were also found: Dr. 5, AC 4 and Gauloise 4 were all manufactured earlier and possibly came into these late layers as refuse. Late types such as North African (Phases 5 and 7), Kapitän II (Phases 6-7) also appeared. Counts of the material showed that amphorae from Aegean (50\%) and Istrian (12\%) factories dominated in the North-East quarter (mainly in the early building phases) while the proportion of material from other factories (Hispania: 11\%, North African: 3\%, Gallia: $1 \%$ ) is lower. The proportion (23\%) of amphorae manufactured somewhere in the Danube region, Moesia, Dacia or Pannonia, transporting regional goods is also significant (cheaper wine?). The above-mentioned data correspond well to the proportions of amphorae finds from the whole province.

\section{Coins}

The examination of the startigraphically valuable coins found in the North-East zone of the settlement resulted in a situation already observed elsewhere in the town: the earliest coins were those of Domitian and Trajan, discovered in the fill of the semi-subterranean features of the early settlement; coins of Trajan significantly increase later (Phase 3). The largest number is the coins of Antoninus Pius. The number of coins decreases in Phase 4, possibly due to the economic crises connected to the Marcomann wars. However, coin circulation reaches its peak during the time of Severan prosperity, the heyday of the North-East quarter and also elsewhere in the town. While the first members of the Severan dynasty are only represented by a few coins, those of Severus Alexander are more numerous. There is a sharp decline again in Phase 6 due to the political - economical crises of the middle of the 3rd century AD (only a single coin can be related to Gordian III in this phase) and after a brief boom (Phase 7) coins disappear completely (Phase 8). The 4th century AD horizon, which cannot be securely attested in this zone yet, is only represented by a coin associated with Constantine II (stray find).

\section{Pannonian stamped pottery}

The more than 271 fragments of so-called Pannonian stamped pottery were found in this zone only provided dating information on Phases 2 and 3. Most of these finds came into later layers through levelling or disturbance of earlier features. Examining the stratigraphically useful shards revealed that most of them (85\%) can be attributed to one of the subgroups of the recently identified so-called Lágymányos workshop-coterie. This confirms the hypothesis that the workshops dated between the end of the 1st - beginning of the 2nd century of the indigenous settlement of the Lágymányos area were already transporting their 
goods to the early civilian settlement. There were fewer pieces belonging to the coterie of Resatus (8\%) and the also recently identified Aquincum group (7\%). Only one stray find can be attributed to the later Roman period. This shard may be the product of the workshop that operated in the place of the later macellum (it was still active in the first half of the 3rd c. AD). That is to say, there were no Pannonische Glanztonware pieces dating to the middle of the 2 nd century $\mathrm{AD}$ or later. The decline and absence of later stamped (and relief-decorated) pottery can be explained by the importation of mass produced vessels from the Central Gaulish and later the Rheinzabern Samian ware workshops. These factories supplied the province from the first half of the 2nd century AD, superseding the local stamped material.

\section{Main results of the dissertation}

Several building phases could be identified in the North-East quarter of the town, based on data from the excavations and finds and evaluated in the present dissertation. These phases fit within the chronological framework of the Aquincum Civil Town resulting in a fourphase settlement history. Beside conclusions about the history of the settlement, new data can hopefully be provided for buildings with problematic functional attributions.

\section{Vicus (Phase 1-2: last quarter - end of 1st century AD)}

Examining the finds and excavation documentation of the North-East quarter it can be concluded - also partially supporting earlier research results - that the first traces of Roman occupation can be found in the western, most elevated part of the North-East zone and can be dated to the last quarter of the 1 st century $\mathrm{AD}$. The core of the settlement may have been formed along the main east-west road (Road "D"), a busy route since prehistoric times which comes from the Solymár-valley and reaches the Danube at this point where there was a good ford and harbour. The earliest settlement horizons are represented by semi-subterranean pit houses, refuse pits, a horse-shoe shaped ditch-and-posthole construction and a ditch running along the main east-west running road. These features suggest the presence of a village-like settlement where dynamic landscaping activity took place: the area sloping down to the river was gradually filled in. Afterwards, based on the excavation data and finds from the North-East zone, the hypothesis of T. Nagy concerning the history, structure and extension of the Aquincum vicus can be updated: a two-phase, "Straßensiedlung" - type of vicus can be reconstructed with rows (?) of pit houses and other features, stretching along the main east-west road.

Archaeological features and finds so far documented in this zone, reveal a solely civilian settlement, with no military character. The settlement was thus a civilian vicus, administratively subordinated to the civitas capital of the Viziváros. It was not developed - as it was also previously postulated by earlier researchers such as L. Nagy and T. Nagy - as an indigenous settlement. Examining the find material from the quarter (Samian ware, oil-lamps, turibula, glass spoons, etc.) also showed that this was a clearly Roman settlement with a Romanized population, even though the pit houses reflect Late Iron Age influence. Celtic traditions are also indicated by the discovery of certain objects such as the rigid heddle, carved antler weaving tool, and the pot with a bone pine placed inside.

Together with D. Gabler and K. Póczy, this data shows that the creation of the civil settlement can be connected to the foundation of the legionary fortress. The relationship between the 
fortress and early Aquincum is partly supported by their dating (last quarter of 1st century $\mathrm{AD})$ and partly by the fact that the distance of the proposed northern edge of the fortress and the southern border of the vicus (approx. Road "E") is 1 leuga $(2.2 \mathrm{~km})$, which corresponds to the average distance between Pannonian fortresses and civil settlements, although this might vary depending on geographical differences. Inhabitants of the settlement may have been Roman citizens, veterans and their families, merchants taking advantage of the busy east-west road and the nearby harbour and indigenous settlers coming from villages (Lágymányos?) in the vicinity looking for a better life.

The borders of the settlement are yet hard to identify as there were only a few large-scale excavations elsewhere in the Civil Town. Only the data from the North-East zone can be relied on so that two possibilities emerge for the borders and form of the early settlement:

- The northern border of the village stretching along the main east-west road could run along the early east-west oriented ditch discovered below the later northern town defences. Its southern border may be marked by another east-west oriented ditch that ran below the southern side of the macellum and the house of Victorinus. It is more difficult to determine the western border as there has been virtually no excavation in the western part of the Civil Town although the earliest cemetery of the settlement, the so-called Aranyhegyi cemetery lying parallel and slightly north of the east-west road (its precise edges are unknown) and the so-called Military Depot pottery workshop (active between the Flavian era and the first decade of the 2nd century $\mathrm{AD}$ ) definitely mark the western edge of the vicus. Likewise, the eastern border is also unknown: the buildings of the former Gas factory and its housing estate and the great depth of fill (due to the sloping surface) prevent any work here. But, the lack of finds and features from the early periods below Building nr. XXIX indicate that this may have been a peripheral area of the vicus.

- The previous hypothesis - that an east-west oriented settlement lay along the main road - was thrown into doubt by the presence of a segment of another early ditch that came to light below the western part of the southern defences of the town. Seeing the problem from this point of view, the first interpretation of the topography of Aquincum by B. Kuzsinszky is also interesting. He originally thought that the western part of the town was occupied by a fort while the buildings in the eastern part, that is, the present archaeological park, belonged to the canabae. Thinking further, the question arises that if there was a fort on the western part (the early southern ditch would then belong to its defence system) did the civilian population settle on its eastern side, in a vicus militaris? If this was the case, the northern, eastern and southern borders of the vicus could have been the same as in the first version, but its western "border" would have been the fortress. The Aranyhegyi cemetery already lay outside the fortress, on its western side. The possible military character of the western side can be further supported by the presence of an early military fort in the area of the Filatori dam that was discovered recently. The timber fort lay on the western side of the main north-south road that ran here. Both features fit into the local Roman demarcation system with the distance between the two features being 0.5 leuga $(1.1 \mathrm{~km})$. Both the above-mentioned hypothesis can only be demonstrated or refuted by further excavations, especially on the western side of the town. What- 
ever the borders and the form of the two-phase vicus were, one thing is certain: the village-like appearance of the settlement changed from the beginning of the reign of Trajan. As data from following phases clearly show, as Aquincum became the capital of the province in $106 \mathrm{AD}$, a process of urbanization began.

\section{Urbanisation (Phase 3-4: beginning - end of the 2nd century AD)}

Becoming the capital of the province and being raised to the rank of municipium 20 years later, must have meant big changes in the life of the village-like settlement. Landscaping activity was still on-going in the North-East quarter. The previously used pits were filled-in and the settlement began to expand towards the river. The first permanent buildings were constructed and already ornamented with frescoes. Some of these constructions were made solely of clay brick, while - and 20 years later this became even more common - some others had stone foundation (with the upper parts still made of clay brick). Recent research has shown that the first street network was marked out in this phase, oriented along the main roads and the aquaeduct that was also built at this time. Tendencies observable in the NorthEast zone also strengthen this hypothesis. Examination of the excavation documentation revealed that the North-East quarter was also involved in this urban planning project. The origin of the strip buildings - later typical for this zone - also date to this period. Plot borders and the form of the insulae were finalized. The function and role of the North-East zone of the settlement slowly changed: focus was shifted to the area along the main north-south road (Road "C") so that the once central part of the settlement became more like a periph eral quarter (especially from the administrative point of view) with industrial and commercial function. One of the most important activities here may have been metal-working, based on the small melting ovens (Buildings nrs. I and XXIX). These features were all placed along Road " $\mathrm{D}$ ", indicating that industry and also perhaps commerce still relied on the busy east-west road.

There are more data about the composition of the population of the settlement in this period. K. Póczy dated the appearance of Cologne citizens in Aquincum to the 2nd century $\mathrm{AD}$. They must have played an important role in the urbanization process and boosted the industrial-commercial life of the area. It cannot be simply an accident that the closest analogies to the strip buildings - by now already visible in the North-East zone and especially in the next period - can be found in the German provinces. The above-mentioned people from Cologne as well as others from the western provinces arriving with the legio II adiutrix must have had an important role in this process.

\section{The colonia (Phase 5-6.: end of 2nd - middle of 3rd century AD)}

The well-known ground plan of the 2nd-3rd centuries AD Civil Town displays differences with the town in the municipium period: the loosely built-in plots disappeared and even their orientations change, even though only slightly. All buildings had stone foundations by now and some - especially the public buildings - had limestone upper parts as well. Based on the present evaluation of the excavation data (Phases 5-6) and earlier research, it is clear that densely built strip houses dominated the North-East quarter, possibly as a result of the economic boom and growing population following the Marcomannic wars. Most of the building remains, still visible today, can be attributed to this period. The present forms of Building nrs. XXVI-XXIX and the Third Bath already existed at this time. Rooms of the 
houses were further divided and hypocaustums were also added (the east wing of Building nr. I and Building nr. XXIX). In some cases, changes in function is also observable: in Building nr. XXIX, the courtyard used for economic purposes was now converted into an atrium. Another typical feature of this period is "wall-pushing": the perimeter walls of several buildings were moved eastwards at the expense of the neighbouring alley/street (eastern perimeter walls of Buildings nrs. XXVII and XXIX). The extent of the movement is different in each case: $1.5-13$ feet $(0.5-4 \mathrm{~m})$. The reason for this phenomenon may be sought in the growing population during the Severan conjuncture and can also be connected to the continuously growing significance of the east-west road and the east-west settlement expansion.

The North-East quarter fits perfectly into the street network - studied in detail by E. Márity of the town in this phase: 1 actus (around $35 \mathrm{~m}$ ) wide blocks can be reconstructed in east-west direction in which the width of buildings - i.e. plots (?) - are fractions of 1 actus, mainly 0.2-0.5 actus. These correspond well with the plot-proportions, widths and lengths of buildings discovered in settlements along the limes in the western Roman provinces (Vindobona, Lopodunum, Bad Wimpfen, Municipium Arae Flaviae).

The main east-west road (Road "D"), possibly already a busy route from prehistoric times, is very important from the point of view of the 3rd century AD use of the north-east. Based on the evaluated excavation data, the industrial and commercial character of this zone sharply amplified in this period. The shorter side of the strip buildings facing Road " $\mathrm{D}$ " were complemented with a "lobby" in every case. Semi-covered rooms were built behind them that possibly functioned as shops. The northern part of the houses were used as a dwelling area. Concrete evidence for industrial activity in this zone could only be shown in the northern part of Building nr. I (a bronze-smithing workshop) and Building nr. XXIX in this period. The latter house provided evidence for glue manufacturing, horn pressing and possibly even tanning. At the same time, other features (such as a terrazzo lined basin in the central part of Building nr. I) indicate other types of activities. Identifying further industrial activities more precisely in this zone could only be done through control-excavations. Activities practiced in this quarter must have involved fire, smelled bad and produced a large amount of waste, which sheds some light on another factor. This zone is very close to the town centre and the quarter inhabited by town magistrates. How could such "dirty" industrial activities have been practiced so close to the centre of the settlement? The reason for this must be the 3rd century AD owners of the workshops (and houses?) who certainly derived a serious income from these businesses, were interested in owning workshops along the main road in such a central area and may even have taken part in the town's public life. Another impor tant factor is the prevailing, northwest-southeast wind, which could have taken smells and smoke away from the town centre towards the river. Apart from the above-mentioned factors, it is also possible that the central position of the strip buildings can be explained by the fact that these plots - as they grew smaller and narrower - were also cheaper. According to A. MacMahon's analogies from Britannia, bigger, quieter plots away from the town centre were bought by well-off town citizens. Based on the above-mentioned factors, the NorthEast zone became a typical, western provincial industrial-commercial quarter (with workshops, tabernae) of the Civil Town in the colonia period. This development must have been the result of deliberate urban planning (along a main road, taking advantage of the wind) and the owners of the workshops could have been influential people who played important roles in public life. 


\section{The last phase (Phase 7: middle of 3rd - 4th century? AD)}

The last examined phase is the interval between the middle of the 3rd and the beginning (?) of the 4th centuries AD. Only a few archaeological features come from this period, so that changes in the functions or ground plans of the buildings- even if any such ever existed can no longer be reconstructed. However, industrial and commercial activity still went on in the eastern wing of Building nr. I. (metal-working) and glue-manufacturing/tanning was also practiced in Building nr. XXIX, where small, taberna-like structures were built in the eastern part of the building. Securely 4 th century AD features or finds have not yet been found in the North-East zone of the town.

The reason for the abandonment of the North-East quarter (or even a larger part of the town?) around the middle of the 3rd century $\mathrm{AD}$ may have been the east-west road that ran down towards the river. The once busy road leading to the harbour could have become just like the riverbank in general - a dangerous area from the middle of the 3rd century AD onwards due to the increasingly frequent Barbarian attacks. Thus, workshops and shop owners could have decided to leave. As the result of economic problems, many workshops may have failed. Even though a true picture of the last phase of life in the town cannot be drawn due to the continuous quarrying activities that started in the Middle Ages, erosion and the damage from early excavations, the quarter could have retained its original industrial-commercial character until it was abandoned.

\section{Buildings and functions}

Several activities were attributed to the 2nd-3rd centuries AD phases of the buildings in the North-East zone over the last 120 years of research. The western and central wings of Building nr. I were considered parts of a basilica based on T. Nagy's research. Based on the excavation documentation and finds from these wings, evaluated in the present dissertation, it seems that even though the function of these building wings may have changed, it could not have been the basilica of the town, based on the ground plan and its relation to the forum. On the basis of the evaluated data, analogies, characteristics of its ground plan and its topographical setting, it seems that the two-winged building may rather have been a mansio, while later it either retained its previous function or became the seat of a collegia (from Phase 5).

The other problematic building in this quarter is the so-called "Diana sanctuary", which was identified by excavators J. Szilágyi and E. Márity. Their hypothesis was based on a basin found inside the building complex, two fragments of mother-of-pearl shell, a piece of a money box and an altar stone dedicated to Diana, found "nearby". The re-evaluated documentation and finds did not provide clear evidence about the function of the complex, but as the altar stone was originally found some $70 \mathrm{~m}$ to the east of the "sanctuary", the whole complex with an inner courtyard was organically attached to Building nr. XXVI. Since there is also a small oven attached to it, it seems more likely to have had a mundane function. Industrial and commercial activity could be best observed in the North-East quarter in at Building nr. XXIX. Metalworking was practiced here in Phases $2-3$, while the owners switched to glue-manufacturing and possibly tanning from Phase 4 onwards as economic conditions changed. The topographical analyses of the immediate neighbourhood of the building showed that raw material supplies and the sale of products of this well known industrial activity, was managed along Road 
"D", possibly also relying on the close-by harbour, the ford and hypothetical slaughtering places by the Danube bank. Examination of the clientele showed that the workshop was not only providing the local population with its goods but possibly also worked for the legionary fortress which must have had a high demand for glue (and partly leather?).

The public utility network (wells and drains) were also examined in the dissertation. The distribution of wells in the various building periods produces an interesting picture. They must also have defined the borders of the plots (that lay in a row) and the first ones were dug in the beginning of the 2nd century $\mathrm{AD}$ (Phase 3) in accordance with topographical observations, while others appeared as the settlement expanded to the east (Phase 4, Building nr. XXIX). However, it seems that after the construction of the aquaeduct only a few wells were constructed (only one later one is known to date!). Examining the drain-network of the town quarter by phases, it may be concluded that the first one was an east-west oriented drainage ditch, dug in the last third of the 1st century AD. By the middle of the 2nd century $\mathrm{AD}$, the main channels running across public land were built of stone and these data fit with results of previous research on the public utilities of the Aquincum Civil Town. The main drains running through public land (below the roads and streets) were constructed at one time and from stone, while smaller channels inside the buildings (i.e. private property) were built later and according to individual needs (from stone or brick or both).

The typical house-form of the 2nd-3rd centuries AD phase of the North-East zone is the socalled strip building ("strip-house" or "Streifenhaus") the origin of which has been the subject of debate (Italian, Gallo-Roman). These houses faced the road along their shorter sides and had a typical inner division (street front part: shop, workshop, back part: dwelling area, back courtyard). The dissertation cites several examples of strip buildings from the Aquincum canabae, in neighbouring Pannonia Superior (Vindobona, Carnuntum), Gallia (Bliesbruch, Malain), Britannia (Verulamium, Venta Belgarum, Sapperton, Corbridge, etc.), Raetia (Vitudurum), Noricum (Karlsdorf, Iuvavum stb.) and Germania Superior (Lopodunum, Arae Flaviae, Bad Wimpfen). The list clearly demonstrates that this type of building was widespread in the western Roman provinces, which can partially be explained by architectural traditions (Gallo-Roman traditions and the influence of Roman military barracks) and partially by the fact that this was the most practical form of house (better use of space) in towns oriented by main roads and vici belonging to the so densely constructed fortresses located along the Western and Central European limes-sections. 


\section{Publications and talks of author related to the topic of the dissertation}

\section{Publications}

LÁNG, O. 2003: Reconsidering the Aquincum macellum: analogies and origins. Acta Archaeologica Academiae Scientiarum Hungaricae 54, 165-204.

LÁNG, O. 2005: The „Peristyl - house”: authenticating excavation in the Northeast part of the Aquincum Civil Town. Aquncumi Füzetek 11, 68-80.

LÁNG, O. 2006: Decorated Pinctada Margaritifera: New data to the Presence of Eastern People in the Civil Town of Aquincum? Communicationes Archaeologicae Hungariae, 149-161.

LÁNG, O. 2007: "Strip house with an atrium residence wing": authenticating excavation in the northeastern part of the Aquincum Civil Town II. Aquincumi Füzetek 12, 117-128.

LÁNG, O. 2008a: Functions and Phases: The „Peristyle - House” in the Civil Town of Aquincum. In: Scherrer, P. (Hrsg.), DOMUS. Das Haus in den Städten der römischen Donauprovinzen. Akten des 3. Internationalen Symposiums über römische Städte in Noricum und Pannonien. Wien, 271-284.

LÁNG, O. 2008b: "Strip house with an atrium residence wing": authenticating excavation in the northeastern part of the Aquincum civil Town III. Aquincumi Füzetek 13, 71-80.

LÁNG, O. 2009: "Unplesant to live in, yet it makes the city rich": Functions of Strip-buildings in the Aquincum Civil Town, in the Light of New Discoveries. In: Bíró, Sz. (ed.), Ex officina. Studia in honorem Dénes Gabler. Győr, 271-286.

LÁNG, O. 2011: Indigenous sanctuary in the northeastern zone of the Aquincum Civil Town - was it ever there at all? In: LazAr, I. (ed.), Religion in public and private space. Acta of the 4th International Colloquium - The Autonomous Towns of Noricum and Pannonia. Koper, 143-156.

\section{Talks}

2005: Functions and Phases: The „Peristyle - House” in the Civil Town of Aquincum. III. Internationalen Symposiums über römische Städte in Noricum und Pannonien. (St. Pölten, 21.04.2005).

2007: "Unpleasant to live in, yet it makes the city rich": functions of strip-buildings in the Aquincum Civil Town in the light of new discoveries. Roman Archaeology Congress. (London, 31.03.2007).

2008: Sanctuaries in the northeastern zone of the Aquincum Civil Town: are they there at all? IV. International Colloquium on Norico-Pannonian autonomous towns. (Celje, 24.09.2008).

2010: Pits and houses: new data to the earliest settlement phases of the Aquincum Civil Town. „Die Dörfliche Siedlungen der römischen Kaiserzeit im Mittleren Donauraum”. (Györ, 07.12.2010).

2011: Smell and urban topography: industry and commerce in the Aquincum Civil Town. ESF Exploratory Workshop "Beyond Marginality: craftsmen, traders and the socioeconomic history of Roman urban communities”. (Oxford, 22.07.2011). 
Urban problems in the civil town of Aquincum: the so-called „northern band”

\begin{tabular}{|c|c|c|c|c|c|c|c|}
\hline & $\begin{array}{l}\text { Periodization of } \\
\text { K. Póczy }\end{array}$ & $\begin{array}{l}\text { K. Póczy } \\
\text { Peacock } \\
\text { house } 1 .\end{array}$ & $\begin{array}{l}\text { P. Zsidi } \\
\text { Peacock } \\
\text { house } 2 .\end{array}$ & $\begin{array}{c}\text { E. Márity } \\
\text { Building XXVI. } \\
\text { „Diana sanctuary” }\end{array}$ & $\begin{array}{l}\text { T. Nagy } \\
\text { Building nr. I. } \\
\text { (Basilica) }\end{array}$ & $\begin{array}{c}\text { J. Szilágyi } \\
\text { Buildings nr. XXVI.-XXVII. } \\
\text { „Diana sanctuary” }\end{array}$ & $\begin{array}{l}\text { O. Láng } \\
\text { Building } n r . \\
\text { XXIX. }\end{array}$ \\
\hline $\begin{array}{c}1 . \\
\text { (pits) }\end{array}$ & & & & 1. & \multirow{2}{*}{ 1. (Prebasilical I.) } & & \\
\hline $\begin{array}{c}2 . \\
\text { (pits,houses) }\end{array}$ & & & & 2. & & 1. & 1. \\
\hline $\begin{array}{c}3 . \\
\text { (adobe walls) }\end{array}$ & „clay-brick ensemble” & 1. & 1. & 3. & 2. (Prebasilical II) & 2. & 2. \\
\hline $\begin{array}{c}4 . \\
\text { (first stone buildings) }\end{array}$ & & 2. & 2., 3. & 4. & 3. (Basilica I.) & 3. & 3. \\
\hline $\begin{array}{c}5 . \\
\text { (,wall-pushing”) }\end{array}$ & „limestone system” & 3. & 4. & 5. & 4. (Basilica II.) & 4. & 4. \\
\hline 6. & $\begin{array}{l}\text { "ashlar, strongly built wall, after } \\
\text { Marcus Aurelius" }\end{array}$ & 4. & 5. & 6. & & & 5. \\
\hline 7. & „moulded walls, macellum-period” & 5. & 6. & 7. & & & 6. \\
\hline 8. & „4th c., stone-in- clay walls” & 6. & 7. & 8. & & & 7. \\
\hline
\end{tabular}

Fig. 2. 
Orsolya LÁNG

\begin{tabular}{|c|c|c|c|c|c|c|c|c|c|c|c|c|}
\hline & $\begin{array}{l}\text { Periodization of } \\
\text { K. Póczy }\end{array}$ & $\begin{array}{c}\text { Terra } \\
\text { sigillata }\end{array}$ & Amphorae & Coins & $\begin{array}{l}\text { Pannonian } \\
\text { stamped pot- } \\
\text { tery }\end{array}$ & Oil-lamps & $\begin{array}{l}\text { Individual finds, } \\
\text { special contexts: } \\
\text { filling of the } \\
\text { horse-shoe } \\
\text { shaped construc- } \\
\text { tion }\end{array}$ & $\begin{array}{c}\text { Individual } \\
\text { finds, spe- } \\
\text { cial con- } \\
\text { texts: gem }\end{array}$ & $\begin{array}{l}\text { Individual finds, } \\
\text { special contexts: } \\
\text { terracotte statuette }\end{array}$ & $\begin{array}{l}\text { Individual } \\
\text { finds, special } \\
\text { contexts: } \\
\text { glass cup }\end{array}$ & $\begin{array}{l}\text { Individual } \\
\text { finds, special } \\
\text { contexts: } \\
\text { rigid heddle }\end{array}$ & $\boldsymbol{\Sigma}$ \\
\hline 1. & & & $\begin{array}{l}\text { middle of 1st } \\
\text { - first quarter } \\
\text { of 2nd c.? }\end{array}$ & & & & & & & & & $\begin{array}{c}\text { last quarter - end } \\
\text { of } 1 \text { st } c .\end{array}$ \\
\hline 2. & & $\begin{array}{l}\text { end of } 1 \text { st - } \\
\text { beginning } \\
\text { of } 2 \text { nd c. }\end{array}$ & $\begin{array}{l}\text { first quarter - } \\
\text { middle of 2nd } \\
\quad \text { c. }\end{array}$ & & $\begin{array}{l}\text { end of 1st - } \\
\text { beginning of } \\
\text { 2nd c. }\end{array}$ & & end of $1 \mathrm{st} \mathrm{c}$. & & & & & $\begin{array}{l}\text { end of } 1 s t-b e g i n- \\
\text { ning of } 2 n d \text { c.? }\end{array}$ \\
\hline 3. & $\begin{array}{c}\text { "clay-brick ensem- } \\
\text { ble" = first decades } \\
\text { of } 2 \text { nd c. }\end{array}$ & $\begin{array}{l}\text { first decade } \\
\text { - middle of } \\
\text { 2nd c. }\end{array}$ & $\begin{array}{l}\text { middle - end } \\
\quad \text { of } \\
\text { 2nd c. }\end{array}$ & $\begin{array}{l}\text { first } \\
\text { decade } \\
\text { - mid- } \\
\text { dle of } \\
\text { 2nd c. }\end{array}$ & $\begin{array}{l}\text { end of 1st - } \\
\text { beginning of } \\
\text { 2nd c. }\end{array}$ & $\begin{array}{l}\text { beginning of } \\
\text { 2nd c. }\end{array}$ & & $\begin{array}{l}\text { beginning of } \\
\text { 2nd c. }\end{array}$ & first decades of $2 \mathrm{nd} \mathrm{c}$. & $\begin{array}{l}\text { end of 1st - } \\
\text { beginning of } \\
\text { 2nd c. }\end{array}$ & & $\begin{array}{l}\text { beginning - mid- } \\
\text { dle of } 2 n d c . ?\end{array}$ \\
\hline 4. & & $\begin{array}{l}\text { middle - } \\
\text { last third of } \\
\text { 2nd c. }\end{array}$ & $\begin{array}{l}\text { third quarter } \\
\text { of } 2 \text { nd }-3 \text { rd c. }\end{array}$ & & $\begin{array}{l}\text { cannot be } \\
\text { valuated! }\end{array}$ & $\begin{array}{l}\text { beginning - } \\
\text { third quarter } \\
\text { of 2nd c. }\end{array}$ & & & & & & $\begin{array}{c}\text { middle - third } \\
\text { quarter of 2nd c. }\end{array}$ \\
\hline 5. & $\begin{array}{c}\text { „limestone system" } \\
=\text { second part of } \\
\text { 2nd c. }\end{array}$ & $\begin{array}{l}\text { last third of } \\
\text { 2nd - be- } \\
\text { ginning of } \\
\text { 3rd c. }\end{array}$ & $\begin{array}{l}\text { turn of 2nd - } \\
\text { 3rd and 3rd c. }\end{array}$ & $\begin{array}{c}\text { middle } \\
- \text { sec- } \\
\text { ond half } \\
\text { of 2nd c. }\end{array}$ & $\begin{array}{l}\text { cannot be } \\
\text { valuated! }\end{array}$ & & & & & & $\begin{array}{l}\text { middle - end of } \\
\text { 2nd c. }\end{array}$ & $\begin{array}{l}\text { last third of } 2 n d- \\
\text { beginning of } 3 r d c .\end{array}$ \\
\hline 6. & $\begin{array}{l}\text { „ashlar, strongly } \\
\text { built wall, after } \\
\text { Marcus Aurelius” } \\
\text { = 3rd c. }\end{array}$ & $\begin{array}{l}\text { beginning - } \\
\text { first half of } \\
\text { 3rd c. }\end{array}$ & 3rd c. & $\begin{array}{l}\text { first } \\
\text { third of } \\
\text { 3rd c. }\end{array}$ & $\begin{array}{l}\text { cannot be } \\
\text { valuated! }\end{array}$ & from the 2 nd c. & & & & & & $\begin{array}{l}\text { beginning - first } \\
\text { half of } 3 r d c .\end{array}$ \\
\hline 7. & $\begin{array}{l}\text { „moulded walls, } \\
\text { macellum-period" } \\
=\text { middle of 3rd c.? }\end{array}$ & $\begin{array}{l}\text { after first } \\
\text { half of } \\
\text { 3rd c.? }\end{array}$ & 3rd c. & $\begin{array}{l}\text { first } \\
\text { third of } \\
\text { 3rd c. }\end{array}$ & $\begin{array}{l}\text { cannot be } \\
\text { valuated! }\end{array}$ & & & & & & & first half of $3 r d c . ?$ \\
\hline 8. & $\begin{array}{c}\text { „4th c., stone-in- } \\
\text { clay walls" = end of } \\
\text { 3rd c.? }\end{array}$ & $\begin{array}{l}\text { after first } \\
\text { half of } \\
\text { 3rd c.? }\end{array}$ & 3rd c. & & $\begin{array}{l}\text { cannot be } \\
\text { valuated! }\end{array}$ & & & & & & & $\begin{array}{c}\text { end of } 3 r d-b e g i n- \\
\text { ning of } 4 \text { th c.? }\end{array}$ \\
\hline
\end{tabular}

Fig. 3. 